\title{
THE FEDERAL RESERVE BOARD REGULATIONS OF COMMON TRUST FUNDS
}

\author{
C. Alexander Capron*
}

An understanding of the regulations issued by the Board of Governors of the Federal Reserve System, concerning the collective investment of trust funds, may be aided by a consideration of some of the problems which are inherent in the use of such funds. Before considering that subject, however, it may be appropriate to mention the occasion for the issuance of such regulations.

Several years ago a few trust companies in various parts of the country set up common trust funds, through which the moneys of various separate trusts might be collectively invested. In each instance the authority to so invest such funds was found only in the instruments creating such trusts. In the absence of express authority to mingle, for the purposes of investment, the funds of a particular trust with those of others, it was recognized that no such collective investment was proper.

At the time or shortly after the first of these funds were established, the question was submitted to the Bureau of Internal Revenue as to whether such a common trust fund was taxable as an association, i.e., whether it would be subjected to corporate taxes. The Bureau ruled that certain of such common trust funds should not be subjected to such corporate taxes. Subsequently, however, the taxation of various types of associations and investment trusts was the subject of litigation and, after the courts had ruled that numerous of such associations and trusts were subject to corporate taxes, the Internal Revenue Bureau was impelled to modify its earlier rulings, and asserted that all such common trust funds should be taxed as corporations.

It was generally recognized by the trust companies that the burden of such corporate taxes was sufficiently heavy to render undesirable the expansion of their program for the collective investment of trust funds. However, many felt that the idea was inherently sound and that their use should not be discouraged by the imposition of such taxes. The problem was presented to the Treasury Department, which was sympathetic to the point of view that relief shoúld be afforded to permit the use of these funds, and did not oppose the adoption of legislation to overcome the difficulty.

- Member of the New York Bar. Member of the firm of Mitchell, Taylor, Capron \& Marsh, Attorneys, of New York City. Member of the sub-committee with respect to Common Trust Funds of the Trust Committee of the American Bar Assóciation. Assisted a committee of the American Bankers Association in its study of common trust funds and in the preparation of its recommendations to the Board of Governors of the Federal Reserve System. 
It was felt necessary to carefully restrict the scope of such legislation so that it might not be used as a cloak for other aggregations of capital. Accordingly, Section $\mathrm{r}^{6} \mathrm{~g}$ of the Revenue Act of 1936 was adopted. ${ }^{1}$ This provides in effect that a common trust fund shall not be considered a corporation or subjected to corporate taxes, that the income of the common trust fund shall be computed as if it were an individual, and that each participating trust shall include, in computing its net income, its proportionate share, whether or not distributed, of the net income of the common trust fund.

To restrict the application of this provision, the term "common trust fund" was defined as a "fund maintained by a bank .... (I) exclusively for the collective investment and reinvestment of moneys contributed thereto by the bank in its capacity as a trustee, executor, administrator, or guardian, and (2) in conformity with rules and regulations, prevailing from time to time, of the Board of Governors of the Federal Reserve System pertaining to the collective investment of trust funds by national banks." This in effect required the formulation of such rules and regulations by the Board of Governors of the Federal Reserve System.

Shortly after the enactment of this statute, a committee of the American Bankers Association was appointed to study this subject and to lend any assistance that might be possible to the Federal Reserve Board. This committee promptly went to work. On numerous occasions it conferred with members of the board and the technical staff, and collected much data on the experience of those funds which had been previously established in this country and the much longer experience of such funds in other countries where they have been extensively used for many years. This data was laid before the Board of Governors of the Federal Reserve System with numerous suggestions concerning the scope of the regulations and the means which might be employed to prevent abuses arising from the use of such common trust funds. After very careful study, the Board issued its regulations to become effective Decernber 3I, .r937. Such regulations constitute Section I7 of Regulation F. Unless otherwise indicated, subsequent references are to subdivisions of that section.

One of the fundamental questions which the establishment and continued use of such common trust funds presents is this. How may equality among the participating trusts constantly be maintained? No difficulty would be presented if all the participating trusts should enter and withdraw at the same time, but this is not contemplated. It is proposed that such funds shall be continuous, permitting additions whenever funds are available for investment, and withdrawal when a participating trust terminates or for some other reason has need of some of the moneys invested in the common trust. Furthermore, it is not contemplated that such funds should consist solely of short term mortgage investments which might be deemed to have a constant market value. The investments of such a common trust should embrace a broad list of securities. The possibility of wide diversification of a large fund is one of the chief advantages of the common trust fund. It must therefore be recog-

${ }^{2} 49$ STAT. 1708, 26 U. S. C. A. \$169 (Supp. 1936). 
nized that the market value of many of the investments of the common trust will fluctuate from time to time. After the fund is once established, when a new trust enters or one of the participating trusts withdraws, the bank managing the common trust fund will occupy the position of buyer as well as seller. As trustee of the trusts already interested in the common fund it will be desirous of obtaining as large a sum as possible for a new participating interest, and as trustee of the trust then acquiring a participation, it will be its duty to pay no more than the fair value of such participation. It is essential, therefore, that rules shall be established for the determination, from time to time, of the fair market value of the whole fund and of the participating interests. It is also of great importance to the banks administering such funds that the determination of the value in good faith, pursuant to the rules so established, shall be conclusive, and not subject to review. They must be protected in any action taken by them in reliance on the value so determined.

The Board of Governors of the Federal Reserve System recognized this problem, but wisely refrained from any attempt to prescribe the precise method of valuing the fund. Instead, its regulations require that a common trust fund shall be operated under a written plan to be approved by a resolution of the board of directors of the bank administering the fund, and that such plan shall contain full and detailed provisions with respect to the basis and method of valuing assets in the common trust fund. Thus, varying methods of valuation may be adopted to meet the conditions prevailing in different places and in connection with different funds.

As illustrative of proper provisions for the valuation of such funds, the regulations issued by the New York State Banking Board may be of interest. The New York Banking Law, Section I0-c(II), authorizes the Banking Board of that state to regulate the conduct and management of common trust funds established pursuant to Section 100-c of such Banking Law. Specific authorization is granted to the Banking Board "after determining the methods and standards by which the fair value of such common trust funds and of the assets and investments thereof may be determined ... to make ... rules and regulations prescribing the methods and standards to be employed by any corporation maintaining such a common trust fund in determining the value thereof and of the assets and investments therein and in establishing the reserves or credits respectively to be deducted from or added to such fund in so determining its value."

Pursuant to this authorization, the New York State Banking Board has issued regulations which prescribe the following method to be used in the valuation of investments:

a. Where there have been recorded sales or bid and asked prices on a security exchange in the city of New York, within ten business days next preceding the valuation date, the trust investment committee shall use for the valuation of each investment of the common trust fund the last recorded sales price, unless subsequent to such sale there shall have been recorded bid and asked prices, in which event the mean of the most recent of such bid and asked prices shall be used. For the purposes of this paragraph recorded sales and bid and asked prices shall be those appearing in newspapers of general circulation pub- 
lished in the city of New York; in standard financial periodicals; or on the records of such security exchanges.

b. In all other cases the trust investment committee shall obtain from three bankers or brokers qualified to give an opinion as to value of the investment in question a written estimate of the value of such investment as of the close of the last business day prior to the valuation date. The average of such estimates shall be used, and each such estimate shall be retained in the records of the common trust fund.

c. An investment purchased and awaiting payment against delivery shall be included for valuation purposes as a security held, and the cash account shall be adjusted to reflect the purchase price.

d. An investment sold but not delivered pending receipt of proceeds shall be valued at the net sales price.

e. For the purpose of valuation of an investment, except an investment sold but not delivered, it shall be unnecessary to deduct from the value ascertained as above indicated brokers' commissions or other expenses which would be incurred upon a sale thereof.

The federal regulations are explicit in providing that funds may be admitted and withdrawn only on the basis of the valuation of the assets of the common trust fund by the trust investment committee of the administering bank, and only on the date the value is so determined, "or if permitted by the plan, within two business days subsequent to the date of such determination." To insure the fact that funds may be withdrawn within a reasonable time after they are needed, the regulations further require that such valuation shall be made at least every three months. ${ }^{2}$

As previously mentioned, the prevailing thought is that additions to and withdrawals from a common trust fund should be permitted. If the establishment of such funds is to present the advantages which are claimed by the advocates of such a system, this is of great importance. The ability promptly to invest comparatively small sums received by a trustee is obviously of importance. Of equal, if not greater importance, is the ability to realize cash through the withdrawal of moneys invested in the common trust fund. The necessity for cash to satisfy annuities or other charges against the principal of a fund, or to distribute the principal upon the termination of the period for which the trust is established is obvious. If provision were not made to permit the prompt withdrawal of funds, it would hardly be prudent for a trustee to enter such a common trust fund. It seems, therefore, that it may be assumed that it is essential to any plan for the establishment of a common trust fund that such provision be made.

It is not sufficient merely to provide machinery to determine the value of the fund and of participations therein. If funds are to be withdrawn, the common trust fund must be so constituted that cash may be realized when a call for such withdrawal is made. This requires some degree of liquidity. Thus the federal regulations provide: "Any bank administering a common trust fund shall have the responsibility of maintaining in cash and readily marketable securities such part of the assets of the common trust fund as shall be deemed by the bank to be necessary

\footnotetext{
'Fed. Res. Bd., Regulation F ("Trust Powers of National Banks"), § 7 (c)(4).
} 
to provide adequately for the needs of participating trusts and to prevent inequities between such trusts."3

This suggests the question as to how inequities between participating trusts might arise, if no participating trust may withdraw more than its share of the value of the whole fund. An example will quickly illustrate how this might occur.' Suppose one trust holds a ten per cent participating interest and ninety per cent of the common trust fund is invested in bonds and mortgages or other assets which may not readily be liquidated. If such participating trust should withdraw its entire interest in the common trust fund, no other trust would be able to withdraw any moneys, no matter how great its need might be. Again suppose that, in a declining market, a large number of participating trusts should withdraw, the tendency of the bank administering the fund might be to sell the best securities as the easiest way of raising the necessary funds. The remaining participating trusts might find their interest frozen in weak or unliquid investments. Obviously the best protection against such untoward results is wise and prudent management. However, the Board of Governors of the Federal Reserve System has erected safeguards to protect all participating trusts against either thoughtless or wilful neglect of this primary obligation to preserve equality in the treatment of all such trusts.

First, the written plan under which the common trust fund is operated must set forth the investment powers. 4

Second, before any distribution in cash is made, the trust investment committee of the administering bank must determine whether any investment remaining in the fund would be unlawful for one or more participating trusts, if funds of such trust were being invested at that time. If there be any such investment, it must be eliminated from the fund before any distribution in cash is made. Such elimination may be made either through a sale thereof, through distribution in kind, or through segregation.

When an investment is segregated, it must be administered or realized upon for the benefit ratably of all trusts participating in the common trust fund at the time of such segregation. Such segregation is treated as a withdrawal of such investment from the common trust fund, although it must, for tax purposes, still be deemed to be part of the common fund. ${ }^{6}$

The effect of these provisions is to permit a trust to withdraw its share of the value of investments which are still sound and eligible, but to prevent any participating trust from taking from the remaining trusts any part of the good assets in payment of its share of the supposed value of any investment which has become ineligible.

Third, it is not sufficient that the remaining investments should be eligible. It is only proper that a fair ratio of liquidity of the fund be preserved and that this should not be destroyed by withdrawals. Thus it is provided that no distribution, other

8Id. $\$ \operatorname{I7}(\mathrm{c})(5)$.

Id. $\$ 17(c)(6)$.
IId. $\$ \operatorname{I7}(\mathrm{c})(\mathrm{I})$.

${ }^{6} I d . \$ 17(c)(7)$. 
than a ratable distribution upon all participations, is permitted at any time, if after all 'withdrawals and additions made at such time, the cash and readily marketable securities are less than forty per cent of the remaining assets. ${ }^{\text {T }}$

The Board has not only placed restrictions on the withdrawal of funds but has also thrown safeguards around the investment of any new funds in a common trust fund. First, no funds of a trust may be invested in a participation without the approval of the trust investment committee of the bank. Second, before permitting any funds to be so invested, such committee must review the investments and if it finds that any such investment is one in which the funds of such trust might not be lawfully invested at that time, the funds of such trust may not be invested in such a participation. ${ }^{8}$ Third, no admission of funds to a common trust fund is permitted at any time, if after all admissions and withdrawals to be made at such time, the ratio of cash and readily marketable securities would be less than forty per cent of the remaining assets. ${ }^{9}$

It will be seen that if a common trust fund is to be continued as an active fund, to which funds may be added or from which they may be withdrawn, it is necessary for the bank administering it to see that the fund embraces only eligible investments, and that a large proportion of these are readily marketable. As soon as an investment ceases to be eligible, it must be sold, or, if a sale is not possible or desirable, it must be segregated and held for the trusts then interested in the common trust fund.

The provision for segregation of investments ceasing to be eligible is very practical and useful. A trustee administering such a fund may be loathe to sell such an investment because of its belief that it is sound and that the investors will lose nothing if they have patience, but such patience should be exercised only in behalf of those who are then interested. New trusts should not be permitted to assume the risks which usually are inherent when an investment ceases to be eligible, nor should those presently interested in such an investment be permitted to withdraw their share until the investment has been liquidated.

Again, it may be impossible to liquidate immediately such an investment. A bond and mortgage may become ineligible because the value of the mortgaged property may depreciate after the money is loaned, but such investment may not be liquidated until and unless there is a default on the part of the mortgagor.

The Federal Reserve Board is to be congratulated on these provisions which should insure that common trust funds governed by such regulations will at all times be made up of good investments described in the plan for such funds, and that such funds will not become clogged with undesirable investments.

No attempt has been made by the Federal Reserve Board to prescribe the investments which may be made by banks administering such common trust funds. This policy of the Board is also to be commended. Flexibility to meet varying purposes and conditions is thus permitted. For example, New York has ena'cted legislation to permit trust companies and banks in that state to invest the funds of estates, trusts,

$$
{ }^{i} I d . \$_{17}(c)(5) \text { (last par.). } \quad{ }^{8} I d . \$_{I 7}(c)(2) . \quad{ }^{\circ} I_{d} . \$_{17}(c)(5) \text { (last par.). }
$$


and guardianships, in a common trust fund established pursuant to such statute and the rules and regulations of the Banking Board of that state. ${ }^{10}$ That statute greatly limits the investments which may be made for such a fund. This, however, does not prevent a New York trust company from establishing another common trust fund with more liberal investment powers for the use of those testators and settlors who believe that greater advantages may be obtained if greater latitude of investments be granted to the trustee.

The proponents of the common trust fund have consistently urged that one of the strongest factors of safety in any investment program is broad diversification. They assert that only through a common fund can small trusts acquire such diversification. In line with this idea, the Federal Reserve Board has embodied in its regulations the following provisions to require diversification: "No investment for a common trust fund shall be made in the stocks, or bonds or other obligations of any one person, firm, or corporation, which would cause the total amount of investment in the stocks, or bonds or other obligations issued or guaranteed by such person, firm, or corporation to exceed ten per cent of the value of the common trust fund, as determined by the trust investment committee, provided that this limitation shall not apply to investments in obligations of the United States or for the payment of the principal and interest of which the faith and credit of the United States shall be pledged."11

A further regulation restricting investments which may be made for a common trust fund embodies another thought, that is, that a bank operating a common trust fund should not invest such a portion of the fund as to acquire a controlling interest therein. Apparently it was the view of the Federal Reserve Board that a more detached judgment as to the worth of an investment may be expected from one who is not in control of the management of a corporation issuing such investment; also that difficulties may be encountered in selling a large proportion of any outstanding issue. Possibly, also, the Board may have entertained the view that it is socially undesirable that common trust funds should be used by banks to obtain control of corporations. Whatever the motive may have been, we find this provision:

No investment for a common trust fund shall be made in any one class of shares of stock of any one corporation which would cause the total number of such shares held by the common trust fund to exceed five per cent of the number of such shares outstanding. If the bank administers more than one common trust fund, no investment shall be made which would cause the aggregate investment for all such common trust funds in shares of stock of any one corporation to exceed such limitation. ${ }^{12}$

Another subject which was a matter of very earnest consideration on the part of the Federal Reserve Board was the possibility of such a common trust fund being used merely as a means of investment, and possibly of speculation, by persons other than the bank acting in a fiduciary capacity. The Board recognized that by the

${ }^{10} \mathrm{~N}$. $\dot{Y}$. BANkJNG LaW, $\$ 100-\mathrm{c}$.

${ }^{21}$ Fed. Res. Bd., Regulation F, §I7(c)(5) (2nd par.).

II. $\$ \operatorname{ly}(\mathrm{c})(5)$ (3rd par.). 
enactment of Section 169 of the Revenue Act of 1936, Congress did not intend to confer tax exemption upon investment trusts in general, but only on an investment trust used exclusively by a bank for the investment of trust funds held by such bank.

Thus it stated: "The purpose of this section ${ }^{13}$ is to permit the use of common trust funds, as defined in section 169 of the Revenue Act of 1936 , for the investment of funds held for true fiduciary purposes; and the operation of such common trust funds as investment trusts for other than strictly fiduciary purposes is hereby prohibited."14

This subject gave rise to very considerable discussion as to whether revocable trusts should not be excluded. It was suggested by some that if the funds of such trusts might be invested in. a common trust fund, a person desiring to invest in the common trust fund might do so by establishing a revocable trust with the bank administering such fund, and direct that the funds be invested in the common trust fund, and that the settlor of such a trust might require the withdrawal of such funds by revoking the trust and demanding the repayment of the trust fund to himself.

On the other hand it was pointed out that bona fide trusts are often established to confer a benefit upon one or more persons who are not trained in the management of investments, where the settlor desires to retain a power of termination or revocation during his lifetime, so that if the management of the trust fund is not satisfactory or conditions change which make it undesirable that the trust should be continued, he may still have control of the situation by revocation of the trust.

The Board of Governors of the Federal Reserve System finally concluded that the mere possibility of a common trust fund being used by others for investment purposes was not sufficient to warrant the exclusion of all revocable trusts from the benefits which it was hoped might be derived through the use of common trust funds. The Board recognized that it was impossible in advance to lay down any fixed rules upon this subject, and therefore place responsibility for the admission or exclusion of such funds upon the trust investment committee of the bank operating the fund. The regulation provides: "The trust investment committee of a bank operating a common trust fund shall not permit any funds of any trust to be invested in a common trust fund if it has reason to believe that such trust was not created or is not being used for bona fide fiduciary purposes."15

To further discourage the use of such funds merely as a medium for investment by persons other than the bank in its fiduciary capacity, the Board further provided: "No bank administering a common trust fund shall issue any document evidencing a direct or indirect interest in such common trust fund in any form which purports to be negotiable or assignable." ${ }^{16}$ It is understood, however, that this provision was not intended to exclude the right of a bank to issue a certificate of participation in an investment which has been segregated and placed in a liquidation account. The issuance of such certificates may be necessary to enable a bank to effect distribution

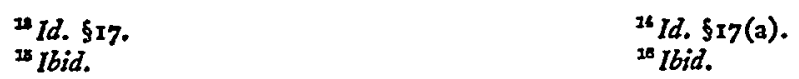


of the principal of a participating trust. While the Board has not officially ruled upon this, it is understood that it would not object to such a certificate being made assignable.

In line with this same thought, that no person should be permitted to speculate through a common trust fund, not even the bank itself, we find a requirement that notice of an intention to participate or withdraw funds from the common trust be given prior to the date of valuation as of which such participation or withdrawal is effected. The regulations indicate that the plan must provide what the length of notice shall be. Notice must be given in writing to the bank or a written notation of the contemplated participation or withdrawal must be made in the records of the bank.17 Since the price for which investments in the common trust will sell in the future on any particular day cannot be known, this requirement of prior notice should prevent any attempt to profit by seeking to gain admission or withdrawal of funds because of the condition of the market on any valuation due. The New York statute requires five days notice. ${ }^{18}$ This provision for notice may also be regarded as one of those provisions through which the Federal Reserve Board has sought to require equality of treatment for all participating trusts.

Another question closely related to the foregoing was the fear. that common trust funds might at some time be embarrassed by something akin to a run, the thought being that if lack of confidence in prevailing conditions should arise, numerous persons having interests in participating trusts might demand the withdrawal of such participations from a common trust fund. It was thought that, if many of such withdrawals should be made at the same time, this might have an injurious effect upon the remaining participants. It was suggested that this possibility might be a real danger if revocable trusts were permitted to invest in a common trust fund. It was pointed out, however, that the banks and trust companies, which had established common trust funds prior to the Ig2g depression and had admitted revocable trusts, had experienced no such runs. It therefore seemed that there was no basis for such fears.

However, it was agreed by all that the withdrawal of too large a proportion of a common trust fund at any time might lead to some embarrassment, and that it was desirable that some limitation should be.placed upon the proportion of a common trust fund which might be owned by any one trust. Accordingly, the Federal Reserve Board provided that no funds of any trust should be invested in a participation in a common trust fund, if such investment would result in such trust having an interest therein in excess of ten per cent of the value of the common trust fund.19

The federal regulations place a further limitation on the amount of any trust which may be invested in a common trust fund. No more than $\$ 25,000$ of any trust may be so invested. Whether any such limitation should be included in the regulations was a subject of much debate, at least among the members of the committee of

${ }^{17} I d .5 \mathrm{x} 7(\mathrm{c})(4)$.

${ }^{13}$ N. Y. BANKING LAW, \$roo-c(6).

${ }^{20}$ Fed. Res. Bd., Regulation F, $\delta$ I7 (c) (5). 
the American Bankers Association. It was thought by some that if the use of a common trust fund for investment purposes was good for a small trust, it was equally desirable for a larger one.

Upon learning that the Federal Reserve Board's technical staff entertained a definite view that some such limitation should be included, the committee discussed the following question: How small a sum may properly be invested and reasonable diversification be obtained? Inquiries upon this subject were addressed to bankers in many parts of the country. The committee was of the view that the common trust fund should be available to any trust which is not sufficient in amount to provide such reasonable diversification in its investments. The replies varied greatly as to the amount required, ranging from $\$ 10,000$ to $\$ 100,000$. What is regarded as a large trust in one section of the country is regarded as meager in the more populous centers.

The result of these inquiries was submitted to the Federal Reserve Board, and the committee expressed the view that if any such limitation were placed on the amount which might be invested by a trust, it should be not less than $\$ 50,000$. Before the Board acted upon this matter, however, legislation was enacted in New York which placed a limit of $\$ 25,000$ on the amount which might be so invested. Undoubtedly this influenced the Federal Reserve Board in its determination to include a similar limitation in its regulations.

While the wisdom of this is doubted by some, recognition must be given to the fact that in the experimental stages of these common trust funds in this country, it is not unreasonable to carefully restrict their use. If they prove as successful as their advocates hope, it should not be difficult to have this regulation modified.

It may be well to note that the regulation limiting the amount which may be invested by a particular trust, must be read carefully. No difficulty is encountered if the funds of any trust are invested in a common trust fund at one time. However, if this be not the case, then the regulation would seem to require that before further funds of the trust are added to the common trust fund, the value of the participation previously acquired for that trust be determined and that only the difference between that value and $\$ 25,000$ may be so invested for that trust.

The regulations are emphatic in providing that a bank administering a common trust fund shall not invest any of its own funds therein; further, that if the bank, because of a creditor relationship, acquires any interest in a participation therein, such participation shall be withdrawn on the first date upon which such withdrawal may be affected. ${ }^{20}$ Nor may the bank have any interest in the assets held in the common trust fund. ${ }^{21}$ Apparently the Board felt that it was of importance that no self-interest should be permitted to influence the bank in its administration of such fund, and that there must be no dealing between the bank in its own right and the common trust fund.

While the Board has not yet officially ruled upon the subject, it is understood that

${ }^{\infty} I d .517(\mathrm{a})(2)$.

${ }^{2} I d . \$ x 7(a)(3)$. 
it was not its intention to prohibit a bank from making a temporary advance of its own funds to a trust holding a participation in a common trust fund. If this be so, such advances as are often made, to supply a trust with moneys to pay expenses or other charges, or to enable the trust to make a payment to an income beneficiary on account of accrued but uncollected income, will still be possible. It is also understood that the Board would not deem it in contravention of this regulation for a bank to loan or advance its own funds against the security of an investment segregated and placed in a liquidation account. This is of importance, for it is likely that it may be necessary that funds be available to protect an investment so segregated. A typical instance would be a bond and mortgage in default. Such a bond and mortgage should be segregated. Funds will be required to pay the expenses of foreclosure, and if the mortgaged property be bought in by the trustee, to provide for rehabilitation of such property. If the necessary funds could not be advanced by the bank, injury might result.

The management of a common trust fund must be exclusively in the bank administering such fund. The regulations wisely provide for this. ${ }^{22}$ Thus, if a trust which owns a participation in such a common trust fund terminates and the principal vests in the remaindermen, such remaindermen may not interfere with the management of the fund by the bank. Moreover, it is understood that the Federal Reserve Board regards it as appropriate for a bank, when acting as one of two or more co-trustees of a particular trust, and when so authorized by the trust instrument or local law governing such trust, to invest such trust funds in a common trust fund. Notwithstanding the fact that there may be one or more co-trustees of a participating trust, the common trust must be managed exclusively by the bank. In view of the phraseology of Section I69 of the Revenue Act of 1936, it would probably be well for banks establishing such common trust funds, to limit investments therein to trusts of which they are the sole trustee, until the Bureau of Internal Revenue has recognized the propriety of so investing funds of which the bank is only one of two or more trustees.

The federal regulations also provide that a bank establishing such a common trust

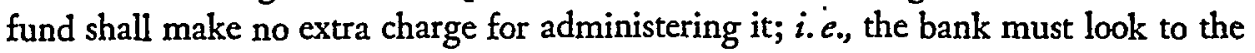
participating trusts for compensation. It is assumed that the bank will receive the same commissions or other compensation from the participating trusts as if they were separately invested. Nor may the bank pay from the common trust funds any fee, commission or compensation for the management thereof, but may pay such reasonable expenses incurred in its administration as would have been chargeable to the participating trusts if incurred in their separate administration. ${ }^{23}$

Other important provisions of the regulations are those relating to the auditing and settlement of accounts of a bank with respect to a common trust fund. Such accounts must be audited annually by auditors responsible only to the board of directors of the bank, and a report of the audit must be sent to each person to whom an

${ }^{2} I d . \delta_{I 7}(\mathrm{c})(8)$.

${ }^{20} I d . \S_{I 7}(\mathrm{c})(8)$. 
accounting of the participating trusts would be ordinarily rendered or such persons must be notified annually that a copy of such report will be sent on request. Detailed provisions concerning the auditing of the accounts of the bank in respect of a common trust fund are found in the regulations. ${ }^{24}$

The settlement of such accounts is, of course, of equal if not greater importance, but no attempt has been made by the Federal Reserve Board to prescribe what method or procedure shall be followed. Apparently the Board recognized that the law prevailing in the different states where such funds are established and the conditions surrounding such funds are apt to vary so greatly that it would be unwise for the Board to endeavor to regulate the settlement of such accounts. It should be noted, however, that the regulations do require that the plan, pursuant to which any such fund shall be established, must contain full and detailed provisions for "the auditing and settlement of accounts of the bank with respect to the common trust fund."25

This requirement is of importance. Great difficulty might develop if no method or procedure be established for the settlement of such accounts. If such accounts be not settled periodically, when the bank as trustee of any particular participating trust is required to render, or voluntarily renders, an account of its proceedings in respect of such trust, undoubtedly it may be required to include therein a full statement of its conduct of the common trust fund during the period such trust had a participation therein, including the valuation thereof both at the time of admission and withdrawal of such participation, and of all other participations in the intervening period. If these common trust funds develop into substantial aggregations of capital, as it is anticipated they will, the burden of defending the administration of the fund in connection with the settlement of the accounts of the bank with respect to each participating trust would be very great. If the bank had its common trust fund accounts prepared periodically, and had many copies of these printed, it might be possible for the bank to include these in accounts rendered by it with respect to the participating trusts. But what of the expense and burden to a participating trust, of having such accounts examined? Assume that the interested parties include a minor for whom a guardian ad litem is appointed. The common trust fund might amount to several million, and the participating interest of such a trust might be a few hundred dollars. Such participating interest might have continued for ten or twenty years. If the guardian should do all that would be required of him in examining the accounts relating to the common trust fund during that period, the expense would either be ruinous to the participating trust or the lack of provision for adequate compensation would render the burden on the guardian intolerable.

It seems, therefore, that it is a practical necessity that some means should be provided for the periodic and final settlement of the accounts of a bank relating to a common trust fund, and that such settlement should be conclusive upon all parties interested in the participating trusts.

24 $1 d . \S \operatorname{IZ}(\mathrm{c})(3)$.

$\approx I d . \oint_{17}(\mathrm{c})(\mathrm{r})$. 
Before discussing what provision should be made for the settlement of such accounts, it is necessary to determine the source of the authority for the investment of funds in the common trust. It is a general principle of equity that trust funds should at all times be separately invested and never mingled with those of other trusts. Authority to depart from this rule must be sought either in the instrument establishing the trust or in a statute of the state, the laws of which control the administration of such trust. Instances of the latter may be found in the statutes of several states authorizing the collective investment of trust funds in bonds and mortgages. Recently New York extended this principle to permit the investment of trust funds in common trust funds established by trust companies pursuant to the Banking Law of that state. ${ }^{20}$ This enactment authorizes such investment of funds of trusts heretofore created as well as those hereafter established.

It is obvious that the settlement of the accounts relating to such a statutory fund should be prescribed by the statute providing for the establishment of such funds, and that care must be taken in such a statute to see to it that the provisions for the settlement of such accounts meet the constitutional requirements for due process of law. The New York statute above mentioned provides for the annual judicial settlement of the accounts of each bank operating a common trust fund. Provision is made for the publication of notice and the appointment of two guardians ad litem, one to represent income beneficiaries who are minors, incompetents, or absentees, and the other to represent similar parties who are remaindermen.

Where investment in the common trust fund is confined to those trusts where specific authority to so invest is conferred by the instrument establishing such trusts, the plan, which should be incorporated by reference in such trust instruments, may provide some practical and inexpensive method for the settlement of the accounts relating to the common trust fund. In some of the plans for such funds which were established before the Board of Governors of the Federal Reserve System issued its regulations, it was provided that an independent auditor should be appointed by some one occupying a semi-public position such as the president of the Chamber of Commerce, and that such auditor should have authority, on behalf of all persons having any interest in the common trust fund, to settle the accounts of the trustee. Provision was further made that in case of dispute between the auditor and the trustee, such dispute should be settled by arbitration.

In providing that the plan pursuant to which such a fund is established, must contain provisions for the settlement of the accounts of the bank administering such a fund, it seems that the Federal Reserve Board had in mind provisions along the lines of those above mentioned. It is believed that the inclusion in the plan of provision for settlement of accounts is essential, not only to comply with the federal regulations, but to meet the practical necessities involved. When a statutory fund is established, undoubtedly it will be sufficient to provide in the plan that the accounts shall be settled in the manner provided in the statute.

\footnotetext{
${ }^{20}$ N. Y. BANKring LAW, §roo-c.
} 
No attempt has been made to mention in detail all the provisions found in the federal regulations. These are succinctly and clearly stated. The purpose of this article has been to state the problems presented in the hope that this might help to explain the purpose and emphasize the importance of some of the provisions found in the regulations.

Before closing, mention should be made of the care taken by the Board, while endeavoring to protect the use of such funds from abuse, to avoid inflicting a penalty upon innocent persons interested in the participating trusts from a failure on the part of the bank to observe all the provisions of such regulations. It will be recalled that the exemption from corporate taxes is only extended by Section 169 of the Revenue Act of 1936 , to those funds which are maintained "in conformity with the rules and regulations prevailing from time to time, of the Board of Governors of the Federal Reserve System. ..." To provide against the disastrous result of such a fund being subjected to corporate taxes because of the innocent failure of the administering bank to observe one or more of these regulations, such regulations conclude with the following:

No mistake made in good faith and in the exercise of due care in connection with the administration of a common trust fund shall be deemed to be a violation of this regulation if promptly after discovery of the mistake the bank takes whatever action may be practicable in the circumstances to remedy the mistake. ${ }^{27}$

But this is not all. The Board has been careful to define the precise method by which controlling facts are to be determined. The trust investment committee of the bank is charged with the duty of determining these, and action taken pursuant to its determination made in good faith, is a compliance with the regulations. For example, such committee must determine whether a trust desiring to participate "was created or is being used for bona fide fiduciary purposes"; whether the fund contains any investments in which a trust so desiring to participate "might not lawfully be in. vested"; the value of the investments, the common fund, and of participating interests therein, as well as the proportion of such fund which consists of cash and readily marketable securities.

In closing, the author desires to pay tribute to the Board of Governors of the Federal Reserve System and its technical staff for the care used to establish practical regulations which should prevent abuses arising in the use of these funds, as well as in framing those regulations so that they may be followed without difficulty, if reasonable care be used by any bank in establishing such a fund.

${ }^{27}$ Fed. Res. Bd., Regulation F, \$17(c)(9). 